\title{
Synthesis, Characterization and Theoretical Study of Some Mixed-ligand Complexes of 2-Quinoline Carboxylic Acid and 4,4 -dimethyl,2,2-Bipyridyl with Some Transition Metal Ions
}

\author{
Mahasin Alias, Sahar Ismael and Souad Abd Mousa \\ Department of Chemistry, College of Science for Women, University of Baghdad, Baghdad-Iraq.
}

\begin{abstract}
New mixed ligand complexes have been prepared by the reaction of Quinoline- 2-Carboxylic Acid (HL1) and 4,4 -dimethyl,2,2-Bipyridyl (L2) with $\mathrm{Co}(\mathrm{II}), \mathrm{Ni}(\mathrm{II}) \mathrm{Cu}(\mathrm{II}), \mathrm{Zn}$ (II), $\mathrm{Pd}$ (II) and $\mathrm{Au}(\mathrm{III})$ ions. The newly prepared complexes were isolated and characterized by (FT-IR) and (UVVis) spectroscopy, elemental analysis, flame atomic absorption technique, thermo gravimetric analysis, in addition to magnetic susceptibility and conductivity measurements. A theoretical treatment of these ligands and prepared complexes in gas phase were studied using Hyper chem. 8 program, moreover, ligands in gas phase also have been studied using Gaussian program (GaussView Currently Available Versions (5.0.9) along with Gaussian 09 which is the latest in the Gaussian series of programs).
\end{abstract}

Keywords: Quinoline-2-Carboxylic Acid, 4,4-dimethyl,2,2-Bipyridyl, Hyperchem.8,spectroscopy, Theoretical treatment, Gaussian program.

\section{Introduction}

Quinoline carboxylic acids and their analogues show a wide variety of medicinal properties including antitumor [1], antiviral [2], and estrogenic activity [3]. Recent demonstrations reveal that quinoline-2carboxylic acid can be used as potential anticancer agents [4], and a biological compound involved in the metabolism of tryptophan. It is a strong chelator that provides the donor set similar to that responsible for binding metal ion in pyrroloquinilnequinone cofactor of quinoprotein family [5]. 2,2'Bipyridine is known to form stable chelate complexes even with low valent transition metal ions [6]. Today, it is even one of the most widely used chelate systems in coordination chemistry and in recent years has also become a very popular ligand in supramolecular and macromolecular chemistry [7]. A quinoline-2-carboxylic acid and coligand 4,4-dimethyl-2,2-Bipyridyl did not receive any attention in spite of well-defined applications of both molecules. Hence, it was thought to explore the study, synthesis and characterization of some new complexes of quinoline-2-carboxylic acid and co- ligand 4,4 dimethyl-2,2-Bipyridyl as mixed ligand complexes.

\section{Experimental}

\subsection{Physical Measurements and Analysis}

Melting point apparatus of Gallen Kamp M.F.B-60 was used to measure melting points of all compounds.FT-IR spectra were recorded as CsI discs using FT-IR3800 Shimadzu in the range of $\left(4000-200 \mathrm{~cm}^{-1}\right)$. Electronic spectra were obtained using UV-1650PC Spectrophotometer at room temperature in DMF solvent. Conductivity was measured by capacitor analyzer in DMF solution $\left(10^{-3} \mathrm{M}\right)$ at room temperature using (WTW) Conductometer. Elemental analysis was performed by using EM-017mth instrument.

Magnetic susceptibility measurements were obtained at $25{ }^{\circ} \mathrm{C}$ Magnetic Susceptibility Balance of Johnson matty catalytic system division, England. The metal percent of all the complexes were determined by using GBS933 Flam plus Atomic Absorption Spectrophotometer. The thermal analysis of all the prepared complexes have been carried out by 4000 Perkin-Elmer thermal analyzer maintained at a $20.00{ }^{\circ} \mathrm{C} \mathrm{min}{ }^{-1}$ heating rate.

\subsection{Synthesis of Metal complexes}

A solution containing the primary ligand Quinoline-2-Carboxylic acid in $10 \mathrm{ml}$ of absolute ethanol, and the secondary ligand 4,4/-dimethyl-2,2/- Bipyridyl in $5 \mathrm{ml}$ of absolute ethanol were added to a $5 \mathrm{ml}$ warm 
absolute ethanol of metal salts $\mathrm{Co}\left(\mathrm{NO}_{3}\right)_{2} \cdot 6 \mathrm{H}_{2} \mathrm{O}, \mathrm{Ni}\left(\mathrm{NO}_{3}\right)_{2} \cdot 6 \mathrm{H}_{2} \mathrm{O}, \mathrm{Cu}\left(\mathrm{NO}_{3}\right)_{2} .3 \mathrm{H}$ ${ }_{2} \mathrm{O}, \quad\left(\mathrm{CH}_{3} \mathrm{COO}\right)_{2} \mathrm{Zn} \cdot 2 \mathrm{H}_{2} \mathrm{O} \quad, \mathrm{PdCl}_{2}$, and $\mathrm{HAuCl}_{4} \cdot \mathrm{H}_{2} \mathrm{O}$ in molar ratio 1:1:1 respectively. The mixture was heated and refluxed with stirring for (3-4) hrs. The colored precipitates were filtered, washed several times with ethanol, and finally recrystalized by etherethanol mixture then dried using desiccators.

\section{Results and Discussion}

Some physical properties and data of the ligands (HL1) and (L2) with their metal complexes are given in Table (1). The molar conductivity in DMF solvent indicates the electrolyte behavior of all complexes except Zn (II) complex [8].

Table (1)

Some physical and analytical data for the ligands and their metal complexes.

\begin{tabular}{|c|c|c|c|c|c|c|c|c|}
\hline \multirow[t]{2}{*}{ Comp. } & \multirow[t]{2}{*}{ Color } & \multirow[t]{2}{*}{$\operatorname{M.P}{ }^{o} \mathrm{C}$} & \multirow[t]{2}{*}{ Yield\% } & \multirow{2}{*}{$\begin{array}{c}\text { M.Wt } \\
\text { g.mol }\end{array}$} & \multicolumn{4}{|c|}{$\begin{array}{c}\text { Elemental analysis\% } \\
\text { Found (Calc.) }\end{array}$} \\
\hline & & & & & $C$ & $\boldsymbol{H}$ & $N$ & $M$ \\
\hline $\mathrm{C}_{10} \mathrm{H}_{7} \mathrm{NO}_{2}(\mathrm{HL1})$ & White & $154-156$ & ---- & 173.17 & ---- & ---- & ---- & --- \\
\hline $\mathrm{C}_{12} \mathrm{H}_{12} \mathrm{~N}_{2}(\mathrm{~L} 2)$ & White & 172-174 & ---- & 184.64 & ---- & ---- & ---- & ---- \\
\hline$[\mathrm{CoL1L2}] \mathrm{NO}_{3} .2 \mathrm{H}_{2} \mathrm{O}$ & $\begin{array}{l}\text { Greenish } \\
\text { blue }\end{array}$ & 96-98 & 70.96 & 513.67 & $\begin{array}{l}51.963 \\
(51.40)\end{array}$ & $\begin{array}{l}5.075 \\
(4.28)\end{array}$ & $\begin{array}{l}10.131 \\
(10.90)\end{array}$ & $\begin{array}{c}12.06 \\
(11.46)\end{array}$ \\
\hline$\left[\mathrm{NiHL} 1 \mathrm{~L} 2\left(\mathrm{H}_{2} \mathrm{O}\right)_{2}\right]\left(\mathrm{NO}_{3}\right)_{2} \cdot \mathrm{H}_{2} \mathrm{O}$ & $\begin{array}{c}\text { Pale } \\
\text { green }\end{array}$ & $144-146$ & 77.41 & 594.46 & $\begin{array}{l}45.246 \\
(44.41) \\
\end{array}$ & $\begin{array}{l}3.469 \\
(4.21)\end{array}$ & $\begin{array}{l}10.911 \\
(11.77) \\
\end{array}$ & $\begin{array}{l}10.54 \\
(9.87)\end{array}$ \\
\hline$\left[\mathrm{CuHL1L2}\left(\mathrm{H}_{2} \mathrm{O}\right)_{2}\right]\left(\mathrm{NO}_{3}\right)_{2}$ & Olive & $182-184$ & 86.75 & 581.34 & $\begin{array}{l}44.630 \\
(45.41)\end{array}$ & $\begin{array}{l}3.967 \\
(3.95)\end{array}$ & $\begin{array}{l}11.530 \\
(12.04)\end{array}$ & $\begin{array}{c}11.13 \\
(10.93)\end{array}$ \\
\hline [ZnL1L2(OAC) $\left.\mathrm{H}_{2} \mathrm{O}\right]$ & $\begin{array}{c}\text { Off } \\
\text { White }\end{array}$ & 116-118 & 70.37 & 499.13 & $\begin{array}{l}56.983 \\
(57.70) \\
\end{array}$ & $\begin{array}{l}5.183 \\
(4.60) \\
\end{array}$ & $\begin{array}{r}7.974 \\
(8.41) \\
\end{array}$ & $\begin{array}{r}12.51 \\
(13.10) \\
\end{array}$ \\
\hline [PdL1L2] Cl.1/2 $\mathrm{H}_{2} \mathrm{O}$ & $\begin{array}{c}\text { Pale } \\
\text { brown }\end{array}$ & $186-188$ & 90.26 & 507.63 & $\begin{array}{l}53.000 \\
(52.00)\end{array}$ & $\begin{array}{l}3.180 \\
(3.54)\end{array}$ & $\begin{array}{l}7.943 \\
(8.27)\end{array}$ & $\begin{array}{c}21.07 \\
(20.98)\end{array}$ \\
\hline [AuL1L2] $\mathrm{Cl}_{2} \cdot \mathrm{H}_{2} \mathrm{O}$ & Brown & $104-106$ & 84.68 & 642.57 & $\begin{array}{l}40.514 \\
(41.08)\end{array}$ & $\begin{array}{l}2.828 \\
(3.11)\end{array}$ & $\begin{array}{l}6.210 \\
(6.53)\end{array}$ & $\begin{array}{c}30.26 \\
(30.66)\end{array}$ \\
\hline
\end{tabular}

\subsection{Infrared Spectra Studies}

Table (2) shows tentative assignments of the IR peaks for the free quinoline -2carboxylic acid and some metals together with the co-ligand 4,4'-dimethyl-2,2' Bipyridyl. The (HL1) may coordinate with metal ions through monodentate, bidentate chelating and bridging according to Nakamoto and Deacon \& Phillips [9].The infrared spectrum of the solid state 2-quinaldic acid indicates that it's exists in two tautomeric forms at the same time, as a neutral molecule (quinoline-2-carboxylic acid) and as a zwitter ion (quinolinium-2-carboxylate) [10].IR spectrum of the ligand shows a typical broad band in the range $(3417-2534) \mathrm{cm}^{-1}$ with its maximum at (2939) $\mathrm{cm}^{-1}$ which refers to stretching frequency of $v(\mathrm{O}-\mathrm{H})$ of carboxylic acid $\left[9^{b}\right]$.This can still be observed in the IR spectrum of nickel and copper complexes, this confirmed the incomplete deprotonation of ligand in these complexes [11].On the other hand, the absence of absorption bands in this region in IR spectra for all complexes confirmed the complete deprotonation of the ligand in these complexes [12]. Further confirmation comes from the absence of $\mathrm{C}-\mathrm{O}-\mathrm{H}$ bending peak for $\mathrm{COOH}$ group at $908 \mathrm{~cm}^{-1}$ [13]. The difference of the value between the asymmetric and symmetric stretching of $\mathrm{COO}^{-}$frequencies $\left(\Delta v=v_{\text {sym }} \mathrm{COO}^{-}-v_{\text {asym }} \mathrm{COO}^{-}\right)$of all complexes have been compared in order to predict the coordination mode of metal ions with quinoline-2-carboxylic acid as shown in Table (2). The $\Delta v$ values, for each prepared complexes, indicates the monodentate coordination of the carboxylate group. The bending of $\delta(\mathrm{C}=\mathrm{N})$ in all complexes shifted 
and appeared at the range $(408-393) \mathrm{cm}^{-1}$ with its maximum at $(405) \mathrm{cm}^{-1}$ [14].indicates that the nitrogen atom of quinoline-2-carboxylic acid also had coordinated with metal ions. Furthermore, new bands attributed to $v(\mathrm{M}-\mathrm{O})$ and $v(\mathrm{M}-\mathrm{N})$ which appeared at $(570-520) \mathrm{cm}^{-1}$ and (420-489) $\mathrm{cm}^{-1}$ respectively in all complexes also confirmed L1 had coordinated with the metal ions through oxygen atom of carboxylate group and nitrogen atom $\left[9^{\mathrm{b}}\right]$. The coordination of 4,4'-dimethyl-2,2/ Bipyridyl is indicated by the positive shift of $v(C=C)$ and $v(\mathrm{C}=\mathrm{N})$ ring streching frequencies and the presence of their deformation modes at 1168 and $1936 \mathrm{~cm}^{-1}$. The position of the bands which was found in the spectrum of 4,4'-dimethyl$2,2^{\prime}$ Bipyridyl has been completely changed in the spectra of the complexes where it is used as co-ligand and new bands appeared at $\sim 1560-1590 \mathrm{~cm}^{-1}$ confirming the coordination nature of this ligand, the $424 \mathrm{~cm}^{-1}$ band of 4,4'dimethyl-2,2/ Bipyridyl (C-C out of plane bending) shifts to higher frequency and splits into two components in the complexes which again confirms the coordination of this ligand through two nitrogen atoms [10]. An additional band in the range (260-270) $\mathrm{cm}^{-1}$ which has been observed in all complexes indicates that the nitrogen atoms of the co-ligand coordinates with metal ion [15]. The presence of water molecules causes the appearance of broad $\mathrm{O}-\mathrm{H}$ stretching bands in the region of $3473-3417 \mathrm{~cm}^{-1}$ in most IR spectra of the complexes [16].

Table (2)

Main FTIR bands in $\left(\mathrm{cm}^{-1}\right)$ observed in the spectra of metal ions mixed ligands complexes.

\begin{tabular}{|c|c|c|c|c|c|c|c|c|}
\hline Comp. & $\begin{array}{c}\text { vasy. } \\
\mathrm{COO}^{-}\end{array}$ & $\begin{array}{c}v_{\text {sym. }} \\
\text { COO }\end{array}$ & $v C=O$ & $v C=N+v C=C$ & $\stackrel{v}{M-N}$ & $\stackrel{v}{M-O}$ & $\begin{array}{c}v \\
M-N \\
\text { (Bipy) } \\
\end{array}$ & Others \\
\hline $\mathrm{C}_{10} \mathrm{H}_{7} \mathrm{NO}_{2}(\mathrm{HL} 1)$ & 1580 & 1390 & 1697 & $\begin{array}{l}1604,1535 \\
1508,1473\end{array}$ & --- & ---- & ---- & ---- \\
\hline $\mathrm{C}_{12} \mathrm{H}_{12} \mathrm{~N}_{2}(\mathrm{~L} 2)$ & ---- & ---- & ---- & $\begin{array}{l}1604,1519, \\
1481,1450\end{array}$ & --- & --- & ---- & ---- \\
\hline$[\mathrm{CoL1L2}] \mathrm{NO}_{3} .2 \mathrm{H}_{2} \mathrm{O}$ & 1592 & 1384 & ---- & $\begin{array}{l}1612,1562 \\
1512,1462\end{array}$ & 443 & 570 & 262 & $\begin{array}{c}\mathrm{vOH}=3441 \\
\delta \mathrm{H} 2 \mathrm{O}=848.6 \\
\mathrm{NO}_{3}=1384,1176, \\
964\end{array}$ \\
\hline$\left[\mathrm{NiHL} 1 \mathrm{~L} 2\left(\mathrm{H}_{2} \mathrm{O}\right)_{2}\right]\left(\mathrm{NO}_{3}\right)_{2} \cdot \mathrm{H}_{2} \mathrm{O}$ & 1595 & 1394 & 1693 & $\begin{array}{l}1612,1560 \\
1512,1465\end{array}$ & 489 & 528 & 270 & $\begin{array}{c}\mathrm{vOH}=3402 \\
\delta \mathrm{H}_{2} \mathrm{O}=856 \\
\mathrm{NO}_{3}=1394,1176, \\
968 \\
\end{array}$ \\
\hline$\left[\mathrm{CuHL1L2}\left(\mathrm{H}_{2} \mathrm{O}\right)_{2}\right]\left(\mathrm{NO}_{3}\right)_{2}$ & 1598 & 1381 & 1693 & $\begin{array}{l}1612,1562 \\
1512,1465\end{array}$ & 489 & 524 & 262 & $\begin{array}{c}\mathrm{vOH}=3348.7 \\
\delta \mathrm{H}_{2} \mathrm{O}=856.3 \\
\mathrm{NO}_{3}=1381,1172 \\
948\end{array}$ \\
\hline [ZnL1L2(OAC) $\left.\mathrm{H}_{2} \mathrm{O}\right]$ & 1594 & 1388 & 1697 & $\begin{array}{l}1612,1566, \\
1516,1465 \\
\end{array}$ & 420 & 528 & 266 & $\begin{array}{l}\delta \mathrm{H}_{2} \mathrm{O}=852 \\
\mathrm{OAC}=1728 \\
\end{array}$ \\
\hline [PdL1L2] Cl.1/2 $\mathrm{H}_{2} \mathrm{O}$ & 1572 & 1365 & ---- & $\begin{array}{l}1600,1528, \\
1516,1465\end{array}$ & 455 & 528 & 262 & $v O H=3348.4$ \\
\hline [AuL1L2] $\mathrm{Cl}_{2} . \mathrm{H}_{2} \mathrm{O}$ & 1575 & 1365 & --- & $\begin{array}{l}1604,1527, \\
1506,1454 \\
\end{array}$ & 455 & 536 & 262 & $v O H=3448$ \\
\hline
\end{tabular}

\subsection{Magnetic Moment Study}

The magnetic moment ( $\mu$ eff) for the cobalt (II) complex $\left(\mathrm{d}^{7}\right)$ has been estimated to be (4.56) B.M. This higher value of ( $\mu$ eff) in this complex may be due to the contribution of spin orbital coupling [17]. In nickel (II) complex, it was recorded at (3.11) B.M. [18], while the ( $\mu$ eff) of the cupper (II) complex is (2.11) B.M [19]. This value lies within the expected value for one electron. On the other hand, zinc (II), palladium (II), and gold (III) complexes are diamagnetic Table (3).

\subsection{The Electronic Spectra \\ 3.3.1. Electronic Spectra of Ligands}

The electronic spectrum of $\mathrm{H} \mathrm{L1}$ exhibits four main bands appeared at $45045 \mathrm{~cm}^{-1}$, $41666 \mathrm{~cm}^{-1}, 34843 \mathrm{~cm}^{-1}$, and a shoulder band at $30487 \mathrm{~cm}^{-1}$ due to $\left(\pi \rightarrow \pi^{*}\right), \quad\left(\mathrm{n} \rightarrow \pi^{*}\right)$, $\left(\mathrm{n} \rightarrow \pi^{*}\right)$ and $\left(\mathrm{n} \rightarrow \pi^{*}\right)$ transitions respectively 
[20]. While the Electronic spectrum of L2 exhibits two main bands: the first one appeared at $41152 \mathrm{~cm}^{-1}$ due to interaligand $\left(\pi \rightarrow \pi^{*}\right)$ transition, the second absorption appeared at $33670 \mathrm{~cm}^{-1}$ arises from $\left(\mathrm{n} \rightarrow \pi^{*}\right)$ transition that may be located on nitrogen atom of $-\mathrm{N}=\mathrm{C}-$. A comparative look of electronic absorption spectral data of the ligands and their complexes indicates that $n \rightarrow \pi^{*}$ and $\pi \rightarrow \pi^{*}$ transitions of the ligands has shifted to higher frequencies [20], Table (3).

\subsubsection{Electronic Spectra of [CoL1L2] $\mathrm{NO}_{3} .2 \mathrm{H}_{2} \mathrm{O}$ Complex}

The greenish-blue complex showed three bands at 16583, 16447, and $14947 \mathrm{~cm}^{-1}$ which assigned to ${ }^{4} \mathrm{~A}_{2} \rightarrow{ }^{4} \mathrm{~T}_{1 \mathrm{p}} \quad v_{3}$ transition. This transition is known to be triplet in the divalent cobalt of tetrahedral geometry. This splitting is due to spin orbital coupling [21]; therefore, $v_{3}$ has been calculated as the average of these three bands. While $v_{1}\left({ }^{4} \mathrm{~A}_{2} \rightarrow{ }^{4} \mathrm{~T}_{2}\right)$ and $v_{2}$ $\left({ }^{4} \mathrm{~A}_{2} \rightarrow{ }^{4} \mathrm{~T}_{1}\right)$ could not be seen since which expected to appear in the range out of scale, so the second transition $\left(v_{2}\right)$ calculated theoretically and it has been estimated to be (5393) $\mathrm{cm}^{-1}$, while first transition $\left(v_{1}\right)$ calculated from infrared spectrum and found to be (3441) $\mathrm{cm}^{-1}$; moreover, $\mathrm{B}^{\prime}, \mathrm{Dq}$, and $\beta$ were calculated and the low value of $\beta$ indicates that the bond is covalent. These parameters are accepted for cobalt (II) tetrahedral complexes [21], Table (3).

\subsubsection{Electronic Spectra of}

\section{[NiHL1L2 $\left.\left(\mathrm{H}_{2} \mathrm{O}\right)_{2}\right]\left(\mathrm{NO}_{3}\right)_{2} . \mathrm{H}_{2} \mathrm{O}$ Complex}

The electronic spectrum of nickel (II) complex showed three bands at 9803, 14662, and $30211 \mathrm{~cm}^{-1}$ which corresponding to ${ }^{3} \mathrm{~A}_{2} \mathrm{~g} \rightarrow{ }^{3} \mathrm{~T}_{2} \mathrm{~g}, \quad{ }^{3} \mathrm{~A}_{2} \mathrm{~g} \rightarrow{ }^{3} \mathrm{~T}_{1} \mathrm{~g}$, and ${ }^{3} \mathrm{~A}_{2} \mathrm{~g} \rightarrow{ }^{3} \mathrm{~T}_{1} \mathrm{~g}_{(\mathrm{p})}$ respectively. The spectrum also shows a band at $13333 \mathrm{~cm}^{-1}$ corresponds to ${ }^{3} \mathrm{~A}_{2} \mathrm{~g} \rightarrow{ }^{1} \mathrm{Eg}$ which refers to forbidden transition. These bands indicate an octahedral geometry around $\mathrm{Ni}$ (II) ion [22]. The absence of the frequency at $(20000) \mathrm{cm}^{-1}$ proves that the prepared complex is not square planer $\left[23^{\mathrm{a}}\right]$. Nephelauxetic factor $\beta$ and Racah parameter $\mathrm{B}^{\prime}$ were calculated by fitting the ratio $v_{3} / v_{2}$ from Tanabe-Sugano diagram for $\mathrm{d}^{8}$ system Table (3).
By fitting the ratio of frequencies $\left(v_{2} / v_{1}\right)$ which equals to 1.5 indicates that the complex has distorted octahedral geometry $\left[23^{b}\right]$, comparable with the value of a regular geometry which equals to 1.6[24]. The formula is further confirmed to be ionic by conductivity measurements. From these results and other analyses, an octahedral geometry around $\mathrm{Ni}$ (II) ion can be proposed

\subsubsection{Electronic Spectra of \\ [CuHL1L2 $\left.\left(\mathrm{H}_{2} \mathrm{O}\right)_{2}\right]\left(\mathrm{NO}_{3}\right)_{2}$ Complex}

Electronic spectrum of $\mathrm{Cu}$ (II) complex shows a broad absorption band at $11695 \mathrm{~cm}^{-1}$ which refers to electronic transition ${ }^{2} \mathrm{~B}_{1} \mathrm{~g} \rightarrow{ }^{2} \mathrm{~A}_{1} \mathrm{~g}$. The second band at $26666 \mathrm{~cm}^{-1}$ which assigned to ${ }^{2} \mathrm{~B} 1 \mathrm{~g} \rightarrow{ }^{2} \mathrm{Eg}$ transition [25], as well as another band at $28653 \mathrm{~cm}^{-1}$ which corresponds to charge transfer from the donor atoms of ligands to cupper (II) ion, Table (3).

\subsubsection{Electronic Spectra of [ZnL1L2(OAC) $\mathrm{H}_{2} \mathrm{O}$ ]Complex}

Since the UV-Visible spectra of $\mathrm{d}^{\mathbf{1 0}}$ ion do not furnish a lot of information, therefore, some shifting and change in the shape of the bands were compared with those of ligands [26]. The prepared off white $\mathrm{Zn}$ (II) complex shows two bands at 41841 and $33444 \mathrm{~cm}^{-1}$, as well as a shoulder at $30864 \mathrm{~cm}^{-1}$.

\subsubsection{Electronic Spectra of [PdL1L2] Cl.1/2 $\mathrm{H}_{2} \mathrm{O}$ Complex}

The spectrum of $\mathrm{Pd}(\mathrm{II})$ complex shows band at 21645 and $28011 \mathrm{~cm}^{-1}$ which are assigned to ${ }^{1} \mathrm{~A}_{1} \mathrm{~g} \rightarrow{ }^{1} \mathrm{~B}_{1} \mathrm{~g}$ and ${ }^{1} \mathrm{~A}_{1} \mathrm{~g} \rightarrow{ }^{1} \mathrm{E}_{1} \mathrm{~g}$ transitions [27], while the band appearing at $31250 \mathrm{~cm}^{-1}$ is correspond to $\mathrm{L} \rightarrow \mathrm{PdCT}$ transition [23b], Table (3), the results are in fairly good agreement with literatures which suggest that $\mathrm{Pd}(\mathrm{II})$ complex has square planer environments of ligands [28].

\subsubsection{Electronic Spectra of [AuL1L2] $\mathrm{Cl}_{2} . \mathrm{H}_{2} \mathrm{O}$ Complex}

The electronic spectrum of this complex Table (3) shows three bands at 26666, $29850 \mathrm{~cm}^{-1}$ which refers to ${ }^{1} \mathrm{~A}_{1} \mathrm{~g} \rightarrow{ }^{1} \mathrm{~B}_{1} \mathrm{~g}$ and ${ }^{1} \mathrm{~A}_{1} \mathrm{~g} \rightarrow{ }^{1} \mathrm{Eg}$ transition respectively, and the third band appeared at $30769 \mathrm{~cm}^{-1}$ due to charge transfer in square planner geometry [29]. 
Table (3)

Electronic spectra, conductance in DMF solvent and magnetic moment (B.M) for ligands and their metal complex.

\begin{tabular}{|c|c|c|c|c|c|c|c|c|}
\hline Comp. & $\begin{array}{c}\mathrm{C}_{10} \mathrm{H}_{7} \mathrm{NO}_{2} \\
(\mathrm{HL} 1)\end{array}$ & $\begin{array}{c}\mathrm{C}_{12} \mathrm{H}_{12} \mathrm{~N}_{2} \\
(\mathrm{~L} 2)\end{array}$ & $\begin{array}{l}{[\mathrm{CoL1L2]}} \\
\mathrm{NO}_{3.2 \mathrm{H}_{2} \mathrm{O}}\end{array}$ & {$\left[\begin{array}{c}{\left[\mathrm{NiHL} 1 \mathrm{~L} 2\left(\mathrm{H}_{2} \mathrm{O}\right)_{2}\right]} \\
\left(\mathrm{NO}_{3}\right)_{2} \cdot \mathrm{H}_{2} \mathrm{O}\end{array}\right.$} & $\begin{array}{c}{[\mathrm{CuHL1L2}} \\
\left.\left.\mathrm{H}_{2} \mathrm{O}\right)_{2}\right] \\
\left(\mathrm{NO}_{3}\right)_{2}\end{array}$ & {$\left[\begin{array}{c}{[\mathrm{ZnL1L2}} \\
\left.(\mathrm{OAC}) \mathrm{H}_{2} \mathrm{O}\right]\end{array}\right.$} & $\begin{array}{l}{[P d L 1 L 2]} \\
C l .1 / 2 \mathrm{H}_{2} \mathrm{O}\end{array}$ & $\begin{array}{c}{[\mathrm{AuL1L2}]} \\
\mathrm{Cl}_{2 .} \mathrm{H}_{2} \mathrm{O}\end{array}$ \\
\hline Absorption & \begin{tabular}{||c|}
$30487(s h)$ \\
34843 \\
41666 \\
45045
\end{tabular} & $\begin{array}{l}33670 \\
41152\end{array}$ & $\begin{array}{c}3441 \\
5393 \text { (cal.) } \\
15992 \text { (av.) }\end{array}$ & \begin{tabular}{c|c|}
13333 \\
9803 \\
14602 \\
30211
\end{tabular} & $\begin{array}{l}11695 \\
26666 \\
28653\end{array}$ & \begin{tabular}{|c}
$30846(\mathrm{sh})$ \\
33444 \\
41841
\end{tabular} & $\begin{array}{l}21645 \\
28011 \\
31250\end{array}$ & $\begin{array}{l}26666 \\
29850 \\
30769\end{array}$ \\
\hline Assignment & $\begin{array}{l}\mathbf{n} \rightarrow \pi^{*} \\
\mathbf{n} \rightarrow \pi^{*} \\
\mathbf{n} \rightarrow \pi^{*} \\
\boldsymbol{\pi} \rightarrow \pi^{*}\end{array}$ & $\begin{array}{l}\mathbf{n} \rightarrow \pi^{*} \\
\boldsymbol{\pi} \rightarrow \pi^{*}\end{array}$ & $\begin{aligned}{ }^{4} \mathbf{A}_{2} & \rightarrow{ }^{\mathbf{4}} \mathbf{T}_{2} \\
{ }^{4} \mathbf{A}_{2} & \rightarrow{ }^{\mathbf{4}} \mathbf{T}_{1} \\
{ }^{4} \mathbf{A}_{2} & \rightarrow{ }^{4} \mathbf{T}_{1(\mathbf{P})}\end{aligned}$ & $\begin{array}{c}{ }^{3} \mathrm{~A}_{2} \mathrm{~g} \rightarrow{ }^{1} \mathrm{Eg} \\
{ }^{3} \mathrm{~A}_{2} \mathrm{~g} \rightarrow{ }^{3} \mathrm{~T}_{2} \mathrm{~g} \\
{ }^{3} \mathrm{~A}_{2} \mathrm{~g} \rightarrow{ }^{3} \mathrm{~T}_{1} \mathrm{~g} \\
{ }^{3} \mathrm{~A}_{2} \mathrm{~g} \rightarrow{ }^{3} \mathrm{~T}_{1} \mathrm{~g}\end{array}$ & $\begin{array}{c}{ }^{2} \mathrm{~B}_{1} \mathrm{~g} \rightarrow{ }^{2} \mathrm{~A}_{1} \mathrm{~g} \\
{ }^{2} \mathrm{~B}_{1} \mathrm{~g} \rightarrow{ }^{2} \mathrm{Eg} \\
\mathrm{L} \rightarrow \mathrm{CuCT}\end{array}$ & $\begin{array}{l}\text { ILCT } \\
\text { ILCT } \\
\text { ILCT }\end{array}$ & $\begin{array}{c}{ }^{1} \mathrm{~A}_{1} \mathrm{~g} \rightarrow{ }^{1} \mathrm{~B}_{1} \mathrm{~g} \\
{ }^{1} \mathrm{~A}_{1} \mathrm{~g} \rightarrow{ }^{1}{ }^{1} \mathrm{Eg} \\
\mathrm{L} \rightarrow \mathrm{PdCT}\end{array}$ & $\begin{array}{r}{ }^{1} \mathrm{~A}_{2} \mathrm{~g} \rightarrow{ }^{1} \mathrm{~B}_{1} \mathrm{~g} \\
{ }^{1} \mathrm{~A}_{2} \mathrm{~g} \rightarrow{ }^{1} \mathbf{E g} \mathrm{E} \\
\mathrm{L} \rightarrow \mathrm{AuCT}\end{array}$ \\
\hline $\mathbf{B}^{\mathbf{0}}$ & --- & --- & 971 & 1035 & --- & --- & --- & --- \\
\hline $\mathbf{B}^{\prime}$ & --- & --- & 737.5 & 917.6 & --- & --- & --- & --- \\
\hline$\beta$ & ---- & --- & 0.75 & 0.88 & --- & --- & --- & --- \\
\hline $\mathbf{D q} / \mathbf{B}^{\prime}$ & ---- & --- & 0.47 & 1.1 & --- & --- & ---- & --- \\
\hline 10Dq & --- & --- & 3460 & 9900 & --- & --- & --- & --- \\
\hline $15 \mathrm{~B}^{\prime}$ & --- & --- & 11062 & 989.9 & --- & --- & --- & --- \\
\hline$\mu_{\text {eff }}$ & --- & --- & 4.56 & 3.11 & 2.11 & 0.00 & 0.00 & 0.00 \\
\hline$\mu_{s \mathrm{sm}^{-1}}$ & --- & --- & 76.6 & 72.7 & 72.2 & 16.6 & 73.4 & 52.6 \\
\hline $\begin{array}{l}\text { Suggested } \\
\text { Structure }\end{array}$ & --- & ---- & T.d & O.h & O.h & O.h & $\begin{array}{l}\text { Sq. } \\
\text { Planer }\end{array}$ & $\begin{array}{c}\text { Sq. } \\
\text { Planer }\end{array}$ \\
\hline
\end{tabular}

ILCT: Internal ligand charge transfer.

\subsection{Thermal Analysis}

Thermal analyses were done to confirm the presence of water molecules as suggested in the new prepared complexes by following the degradation steps in TG curves and the obtained results has been listed in Table (4).

Table (4)

Thermal analytical data of the water molecule for the newly prepared complexes.

\begin{tabular}{|c|c|c|}
\hline Comp & $\begin{array}{c}\text { Weight loss } \\
\text { found (Calc.)\% }\end{array}$ & $\begin{array}{c}\text { Temp range in } \\
T G\left({ }^{\circ} \mathrm{C}\right) \\
\end{array}$ \\
\hline [CoL1L2] $\mathrm{NO}_{3.2 \mathrm{H}_{2} \mathrm{O}}$ & $6.51(7.00)$ & $118.93-220.71$ \\
\hline$\left[\mathrm{NiHL1L2}\left(\mathrm{H}_{2} \mathrm{O}\right)_{2}\right]\left(\mathrm{NO}_{3}\right)_{2} \cdot \mathrm{H}_{2} \mathrm{O}$ & 8.58(9.08) & 129.65-170.22 \\
\hline$\left[\mathrm{CuHL1L2}\left(\mathrm{H}_{2} \mathrm{O}\right)_{2}\right]\left(\mathrm{NO}_{3}\right)_{2}$ & 4.71(5.19) & $122.15-192.62$ \\
\hline [ZnL1L2(OAC)H $\left.\mathrm{H}_{2} \mathrm{O}\right]$ & $2.93(3.63)$ & 282.33 \\
\hline [PdL1L2] Cl.1/2 $\mathrm{H}_{2} \mathrm{O}$ & 0.98(1.07) & 72.60-225.86 \\
\hline [AuL1L2] $\mathrm{Cl}_{2} \cdot \mathrm{H}_{2} \mathrm{O}$ & $2.92(2.80)$ & $74.90-220.10$ \\
\hline
\end{tabular}



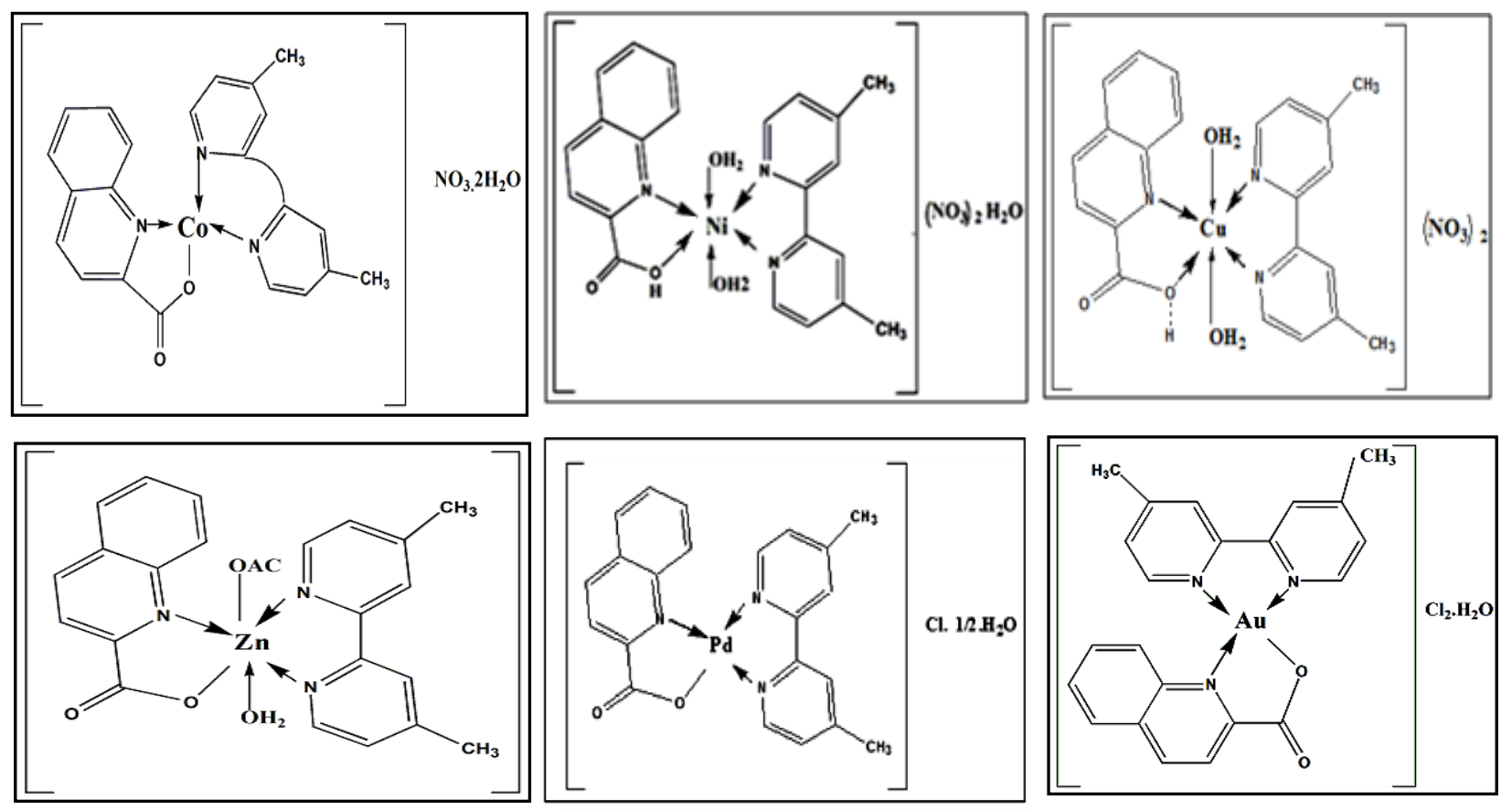

\section{Theoretical Studies}

In this work, Hyperchem.8 program has been used to calculate The heat of formation $\left(\Delta \mathrm{H}_{\mathrm{f}}^{\mathrm{o}}\right)$, binding energy $\left(\Delta \mathrm{E}_{\mathrm{b}}\right)$ and dipole moment $(\mu)$ for the free ligands and their metal complexes using semi-empirical (ZINDO/I, PM3) and molecular mechanics (AMBER ) methods at $298 \mathrm{~K}$. It was found that the complexes are more stable than their ligands Table (5); Furthermore, the electrostatic potential for free ligands was calculated to investigate the reactive site of the molecules, PM3 was used to evaluate the vibrational spectra of free ligands. It has been found that these obtained frequencies agree well with experimental results; in addition, the calculation helped to assign unambiguously the most diagnostic bands Table (6). Electronic spectra measurements for the ligands were calculated theoretically by using ZINDO/S method and comparing it with the experimental results. It was found that there was a close agreement between the theoretical calculations and experimental results Table (7). While Gaussian program semiempirical (PM3) method was used to calculate the geometry optimization, dipole moment $(\mu)$ and total energy as shown in Table (8). Electrostatic potential, $\mathrm{E}_{\mathrm{LUMO}}$ and $\mathrm{E}_{\mathrm{HOMO}}$ was obtained also; evaluate the vibrational spectra of free ligands, and these obtained frequencies agree well with experimental results as shown in Table (9). Electronic spectra measurements for the ligands were calculated theoretically by using the job type: Single point energy ( $\underline{\mathrm{SP}})$ along with ZINDO method and also the job type Frequency (Freq) used along with CIS method (3-21G) and compared both methods with the experimental results as shown in Table (10). It was found that there was a close agreement between the theoretical and experimental results. 


\section{Table (5)}

Conformation energetic in (Kcal.mol-1) and dipole moment (in Debye) for ligands and their metal complexes using hyperchem-8 program.

\begin{tabular}{|c|c|c|c|c|c|c|c|}
\hline \multirow{2}{*}{ Compound } & \multicolumn{3}{|c|}{ PM3 } & \multicolumn{3}{|c|}{ ZINDO/1 } & AMBER \\
\hline & $\Delta H_{f}^{o}$ & $\Delta E_{b}$ & $\bar{\mu}$ & $\Delta H_{f}^{o}$ & $\Delta E_{b}$ & $\mu$ & $\Delta H_{f}^{o}=\Delta E_{b}$ \\
\hline $\mathrm{C}_{10} \mathrm{H}_{7} \mathrm{NO}_{2}$ (HL1) & -39.8326 & -2345.56 & 3.027 & -4515.74 & -6821.47 & 3.324 & --- \\
\hline $\mathrm{C}_{12} \mathrm{H}_{12} \mathrm{~N}_{2}(\mathrm{~L} 2)$ & 329.69 & -2259.59 & 4.589 & -4860.72 & -7450.01 & 5.209 & ---- \\
\hline$\{\mathrm{CoL1L2}\} \mathrm{NO}_{3} .2 \mathrm{H}_{2} \mathrm{O}$ & --- & --- & --- & -10216.87 & -15474.80 & 13.84 & --- \\
\hline $\begin{array}{l}{\left[\mathrm{NiHL1L2}\left(\mathrm{H}_{2} \mathrm{O}\right)_{2}\right]\left(\mathrm{NO}_{3}\right.} \\
)_{2} . \mathrm{H}_{2} \mathrm{O}\end{array}$ & --- & ---- & --- & -10993.76 & -16631.72 & 8.291 & --- \\
\hline $\begin{array}{l}{\left[\begin{array}{l}{\left[\mathrm{CuHL} 1 \mathrm{~L} 2\left(\mathrm{H}_{2} \mathrm{O}\right)_{2}\right]} \\
\left(\mathrm{NO}_{3}\right)_{2}\end{array}\right.} \\
\end{array}$ & ---- & ---- & --- & -11412.33 & -17028.19 & 12.13 & ---- \\
\hline$\left[\mathrm{ZnL} 1 \mathrm{~L} 2(\mathrm{OAC}) \mathrm{H}_{2} \mathrm{O}\right]$ & --- & --- & --- & -12836.02 & -18803.69 & 10.78 & --- \\
\hline PdL1L2] Cl.1/2 $\mathrm{H}_{2} \mathrm{O}$ & $\begin{array}{l}--- \\
\end{array}$ & $\begin{array}{l}--- \\
\end{array}$ & \begin{tabular}{c|}
--- \\
\end{tabular} & $\begin{array}{l}--- \\
\end{array}$ & $\begin{array}{ll}--- \\
\end{array}$ & $\begin{array}{ll}-- \\
\end{array}$ & 444.01 \\
\hline $\mathrm{AuL1L2]} \mathrm{Cl}_{2} \cdot \mathrm{H}_{2} \mathrm{O}$ & ---- & ---- & --- & ---- & ---- & --- & 48.47 \\
\hline
\end{tabular}

Table (6)

Comparison of experimental and theoretical main vibration frequencies for Qinoline-2carboxylic acid (HL1) and 4,4-dimethyl-2,2'-bipyridyl(L2)using hyperchem-8program

\begin{tabular}{|c|c|c|c|c|}
\hline Symb. & $v(C=O)$ & $v(C=N+C=C)$ & $\delta(C-O)$ & $v(O-H)$ \\
\hline HL1 & $\begin{array}{c}1980.78 \\
1697.36 * \\
(16.69)\end{array}$ & $\begin{array}{c}1631.59 \\
1604 * \\
(1.68)\end{array}$ & $\begin{array}{c}1394.36 \\
1261.45 * \\
(10.54)\end{array}$ & $\begin{array}{c}3852.17 \\
2939 * \\
(4.47)\end{array}$ \\
\hline Symb. & $v(C=N+C=C)$ & v(C-H)aliph. & v(C-H)arom. & 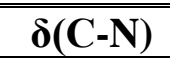 \\
\hline $\mathbf{L 2}$ & $\begin{array}{c}1780.43 \\
1604.77 * \\
(10.94)\end{array}$ & $\begin{array}{c}3170.58 \\
2981.95 * \\
(2.99)\end{array}$ & $\begin{array}{c}3035.50 \\
\text { 3078.39* } \\
(\mathbf{0 . 0 3 3 )}\end{array}$ & $\begin{array}{c}1233.03 \\
1273.02 * \\
(-3.14)\end{array}$ \\
\hline
\end{tabular}

(*) Experimental Frequency Error \%.

Table (7)

Comparison of experimental and theoretical electronic transition for ligands from ZINDO/S calculation and Experiment method using hyper chem-8 program.

\begin{tabular}{|c|c|c|c|}
\hline Symbols & Transition & Experimental & Theoretical(ZINDO/S) \\
\hline HL1 & $\begin{array}{l}\mathbf{n} \rightarrow \boldsymbol{\pi} \\
\mathbf{n} \rightarrow \boldsymbol{\pi}^{*} \\
\mathbf{n} \rightarrow \boldsymbol{\pi}^{*} \\
\boldsymbol{\pi} \rightarrow \boldsymbol{\pi}^{*}\end{array}$ & $\begin{array}{c}328 s h \\
287 \\
240 \\
222\end{array}$ & $\begin{array}{c}306 \\
279.4 \\
229 \\
214\end{array}$ \\
\hline $\mathbf{L 2}$ & $\begin{array}{l}\mathbf{n} \rightarrow \boldsymbol{\pi}^{*} \\
\boldsymbol{\pi} \rightarrow \boldsymbol{\pi}^{*} \\
\mathbf{n} \rightarrow \boldsymbol{\pi}^{*} \\
\boldsymbol{\pi} \rightarrow \boldsymbol{\pi}^{*}\end{array}$ & $\begin{array}{c}297 \\
243 \\
----- \\
----- \\
\end{array}$ & $\begin{array}{c}274.55 \\
----- \\
237.02 \\
195.0 \\
\end{array}$ \\
\hline
\end{tabular}


Table (8)

Conformation energetic in (Kcal.mol $\left.{ }^{-1}\right)$ and dipole moment (in Debye) for ligands (HL1,L2) using Gaussian program.

\begin{tabular}{|c||c||c|}
\hline Compound & Total energy & $\mu$ \\
\hline \hline HL1 & $\mathbf{- 3 2 . 4 4 7 6 2 4 4 9}$ & 3.3846 \\
\hline L2 & 45.4167809 & 3.4377 \\
\hline
\end{tabular}

Table (9)

Comparison of experimental and theoretical vibration frequencies for Qinoline-2-carboxylic acid (HL1) 4,4-dimethyl-2,2'-bipyridyl (L2)using Gaussian programs.

\begin{tabular}{|c||c||c||c||c||}
\hline Symb. & $v(C=O)$ & $v(C=N+C=C)$ & $\delta(C-O)$ & $v(O-H)$ \\
\hline \hline & 2065.71 & 1628.07 & 1282.41 & 3239.37 \\
HL1 & $1697.36 *$ & $1604 *$ & $1261.45 *$ & $2939 *$ \\
& $(17.83)$ & $(1.47)$ & $(1.63)$ & $(9.27)$ \\
\hline Symb. & $v(C=N+C=C)$ & $v(C-H) a l i p h$. & $v(C-H) a r o m$. & $\delta(C-N)$ \\
\hline \hline \multirow{2}{*}{ L2 } & 1745.74 & 3170.22 & 3031.92 & 1228.28 \\
& $1604.77 *$ & $2981.95 *$ & $2981.95 *$ & $1273.02 *$ \\
& $(8.07)$ & $(5.93)$ & $(1.63)$ & $(-3.64)$ \\
\hline
\end{tabular}

(*) Experimental Frequency Error \%.

Table (10)

Comparison of experimental and theoretical electronic transition for ligands from CIS and ZINDO calculation and Experiment method using Gaussian program.

\begin{tabular}{|c|c|c|c|c|}
\hline Symbols & Transition & Experimental & \multicolumn{2}{|c|}{ Theoretical } \\
\hline \multirow[b]{2}{*}{ HL1 } & \multirow[b]{2}{*}{$\begin{array}{l}\mathbf{n} \rightarrow \boldsymbol{\pi} \\
\mathbf{n} \rightarrow \boldsymbol{\pi}^{*} \\
\mathbf{n} \rightarrow \boldsymbol{\pi}^{*} \\
\boldsymbol{\pi} \rightarrow \boldsymbol{\pi}^{*}\end{array}$} & \multirow[b]{2}{*}{$\begin{array}{c}\text { 328sh } \\
287 \\
240 \\
222 \\
\end{array}$} & CIS & ZINDO \\
\hline & & & (222)max & (311.59)max \\
\hline \multirow[b]{2}{*}{$\mathbf{L} 2$} & \multirow[b]{2}{*}{$\begin{array}{l}\mathbf{n} \rightarrow \boldsymbol{\pi}^{*} \\
\boldsymbol{\pi} \rightarrow \boldsymbol{\pi}^{*} \\
\boldsymbol{\pi} \rightarrow \boldsymbol{\pi}^{*}\end{array}$} & \multirow[b]{2}{*}{$\begin{array}{r}297 \\
243 \\
---- \\
\end{array}$} & CIS & ZINDO \\
\hline & & & (185)max & $(279.77) \max$ \\
\hline
\end{tabular}

\section{Conclusion}

In this paper, we succeeded to prepare mixed ligands of (Quinoline-2-carboxylic acid and 4,4dimethyl-2,2-bipyridyl) with some heavy and light transition metal ions. The new solid metal complexes were isolated and characterized using the available conventional techniques. The results indicate that the primary ligand Quinoline-2carboxylic acid behaves as bidentate through the nitrogen and oxygen atoms, while the co-ligand 4,4 -dimethyl-2,2-bipyridyl behaves as bidentate ligand but through the two nitrogen atoms with metal ions. Moreover, the results obtained for the ligands and their complexes which were isolated in solid state were compared with the results obtained from the gas phase study using Hyper Chem- 8 and Gaussian programs exhibited almost identical results between these states.

\section{References}

[1] Srivastava, S.K.; Agarwal, S.K.; Mukherjee, R.; Burman, A.C.; "Synthesis and structure-activity relationships of potent antitumor active quinoline and naphthyridine derivatives." Anticancer Agents Med. Chem., 7(6):pp 685-709; 2007. 
[2] Dayam, R.; Al-Mawsawi, L.Q.; Zawahir, Z.; Witvrouw ,M.; Debyser, Z.; Neamati, N.; "Quinolone 3-carboxylic acid pharmacophore: design of second generation HIV-1 integrase inhibitors."; J. Med. Chem., 51(5):pp1136-44;2008.

[3] Shi, F.; Zhang, S.; Wu, S.S.; Gao, Y.; Tu, S.J.; "A diversity-oriented synthesis of pyrazolo[4,3-f] quinoline derivatives with potential bioactivities via microwaveassisted multi-component reactions." Molecular Diversity; 15(2):pp 497-505; 2011.

[4] Musiol, R.; Jampilek, J.; Kralova, K.;Richardson, D. R.; Kalinowski, D.; Podeszwa, B.; Finster, J.; Niedbala, H.; Palka, A.; Polanski , J.; "Investigating biological activity spectrum for novel quinoline analogues";Bioorg.Med. Chem.; 15(3):pp1280-1288; 2007.

[5] Dobrzyńska, D.; Lis, T.; Jerzykiewicz, L. B.; "3D supramolecular network constructed by intermolecular interactions in mixed ligand complex of zinc"; Inorg. Chem.Comm.; 8(12):pp 1090-1093;2005.

[6](a) Kinnunen, T. J. J.; Haukka, M.; Pesonen E.; Pakkanen, T. A.; " Rutheniu complexes with 2,2'-, 2,4'- and 4,4'- Bipyridine ligands:The role of Bipyridine coordination modes and halide ligand"; J. Organo. Chem.; 655 (1-2): pp 31-38; 2002.

(b) Ardon, M.; Hogarth, G.; Oscroft, D.T.W.; "Organometallic chemistry in a conventional microwave oven: the facile synthesis of group 6 carbonyl complexes"; J. Organo. Chem.; 689 (15):pp 24292435;2004.

[7] (a) Schubert, U.S.; Eschbaumer, C.; "Macromolecule Containing Bipyridine and Terpyridine Metal Complexes: Towards Metallosupramolecular Polymers"; Angew. Chemie. International Edition; 41(16): pp 2892-2926;2002.

(b) Kaes, C.; Katz, A.; Hosseini, M.W.; "Bipyridine: The Most Widely Used Ligand. A Review of Molecules Comprising at Least Two 2, 2'-Bipyridine Units”; Chem. Rev.; 100(10) : pp 35533590; 2000.

[8] (a) Dutt, N.K.; Chakder, N.C.; "Complexes of cobalt (II) with some thiocarbazide derivatives"; J. Inorg. Nucl. Chem. 33 (2): pp 393-403; 1971.

(b) Chow, S.T., McAuliffe, C.A.; "Metal complexes of amino acids and derivativesXIII Some nickel (II) complexes of Larginine zwitterions or L-argininate anions. A novel ionic $\rightarrow$ bidentate perchlorate rearrangement brought about by pressure[1-5]"; J. Inorg. Nucl. Chem.; 37(4):PP1059-1064; 1975.

[9] (a) Deacon, G.B.; Phillips, R.J.; "Relationships between the carbon-oxygen stretching frequencies of carboxylato complexes and the type of carboxylate coordination"; Coord. Chem. Rev.; 33: pp 227-250; 1980

(b) Nakamoto, N.; "Infrared and Raman Spectra of Inorganic and Coordination Compounds"; John Wiley \& Sons, Inc., $6^{\text {th }}$ Ed., New Jersey; 2009.

[10] Mceleverty, J.A.; Gill, S.A.;Kowalski, R.S.; Billy, N.A.; Admas, H.; Lumbard, K.W.; and Murphy, M. A.; " Aspects of the inorganic chemistry of rubber vulcanization. Part 3. Anionic cadmium complexes derived from dialkyldithiocarbamates, 2-mercapt-obenzothiazole and its derivatives, and dialkyl dithiophosphates, and the crystal and molecular structures of $\left[\mathrm{NBu}_{4}{ }_{4}\right]\left[\mathrm{Cd}\left(\mathrm{S}_{2} \mathrm{CNEt}_{2}\right)_{3}\right]$, $\left[\mathrm{NEt}_{4}\right]\left[\mathrm{Cd}\left(\mathrm{C}_{7} \mathrm{H}_{4} \mathrm{NS}_{2}\right)_{3}\right]$, and $\left[\mathrm{NMe}_{4}\right]\left[\mathrm{Cd}\left\{\mathrm{S}_{2} \mathrm{P}\left(\mathrm{OPr}^{\mathrm{i}}\right)_{2}\right\}_{3}\right]$ "; J. Chem. Soc. Dalton. Trans.; (3): PP 493-503; 1982.

[11] (a) Qin, C.; Wang, X. L.; Wang, E. B.; Su, Z. M.; " A Series of Three-Dimensional Lanthanide Coordination Polymers with Rutile and Unprecedented RutileTopologies" Inorg. Chem.; 44(20):pp 71227129; 2005.

(b) Yong, G.P.; Wang, Z.Y.; Cui, Y.; "Synthesis, Structural Characterization and Properties of Copper (II) and Zinc (II) Coordination Polymers with a New Bridging Chelating Ligand"; E-J Inorg. Chem.; (21): pp 4317-4323; 2004.

[12] (a) Zhang, G.Q.; Wang, Q.; Qian, Y.; Yang, G.Q.; Ma, J. S.; "Synthesis, characterization and photoluminescence properties of two new europium (III) coordination polymers with 3D open framework"; J. Mole. Struc.; 796:pp187194; 2006. 
(b) Du, M.; Zou, R.; Zhong, R.; Xu, Q.; "Hydrothermal synthesis, crystal structures and properties of new $\mathrm{Fe}(\mathrm{II}), \mathrm{Co}(\mathrm{II})$, $\mathrm{Ni}(\mathrm{II})$, and $\mathrm{Zn}(\mathrm{II})$ complexes with 6quinolinecarboxylate: Interplay of coordinative and noncovalent interactions" ; Inorg. Chim. Acta.; 361:PP 1555-1561; 2008.

[13] (a) Ye, Q.;Chen, X.; Song, Y.; Wang, X.; Zhang, J.; Xiong, R.; Fun, H.; You, X.; “ A blue fluorescent $\mathrm{Cd}$ (II) coordination polymer with 3, 5-diaminobenzoic acid ligand: synthesis, crystal structure and fluorescent property"; Inorg. Chim. Acta.; 358:pp 1258-1262; 2005.

(b) Zhang, Y.N.; Liu, J.Q.; Wang, T.; Wen, G.L.; Yang, G.P.; Wang, Y.Y.; Shi, Q. Z.; "Design and syntheses of two novel Mn(II) and $\mathrm{Cu}$ (II) complexes with 2,2-biquinoline4,4'- dicarboxylate and N-containing bidentate co-ligand" ; J. Molec. Stru.; 878:pp116-123;2008.

[14] Zurowska, B.;Mrozinski, J.; "Isomeric forms of $\mathrm{Cu}$ (quinoline-2-carboxylate) ${ }_{2} \mathrm{H}_{2} \mathrm{O}$ Spectroscopic and magnetic properties"; Materials Science-Poland; 23(3):pp737744; 2005.

[15] Andrews, P.C.; Koutsanonis, G.A.; and Raston, C.L.; "Synthesis and crystal structures of [C6H4SC (S) NNa・3P $(\mathrm{NMe} 2) 3 \mathrm{O} \cdot \mathrm{NaN} \quad(\mathrm{S}) \mathrm{CSC} 6 \mathrm{H} 4]$ and [C6H4SC (S) NLi • pmdien] (pmdien $=\mathrm{N}, \mathrm{N}, \mathrm{N}^{\prime}, \mathrm{N}^{\prime \prime}, \mathrm{N}^{\prime \prime}$-pentamethyldiethylenetriamine): alkali-metal amides from 2sulfanylbenzothiazole"; J. Chem. Soc. Dalton. Trans.; 24:pp 4059-4065; 1995.

[16] Cho, J.; Lough, A.J.; and Kim, J. C.; "Monomeric and polymeric copper (II) hexaaza macrocyclic complexes with btc anions (btc=1,2,4,5-benzenetetracarboxylic acid)"; Inorga. Chim. Acta.; 342:pp 305310; 2003.

[17] Datt, N.K.; Chakder, N.C.; "Complexes of cobalt (II) with some thiocarbazide derivatives"; J.Inorg. Nucl.Chem.; 33(2): pp 393-403; 1971.

[18] Nath, P.; Dhumwad , S . D.; "Synthesis, characterization and antimicrobial studies of $\mathrm{Co}(\mathrm{II}), \mathrm{Ni}(\mathrm{II}), \mathrm{Cu}(\mathrm{II})$ and $\mathrm{Zn}$ (II) complexes derived from a Schiff base of 2-[(4-Methyl2-oxo-2H-chromen-7-yl) oxy]acetohydrazide with 3-formyl-2-hydroxy quinoline and 3-formyl-2-mercapto quinoline"; Journal of Chemical and Pharmaceutical Reasarch; 4(1): pp851-865; 2012.

[19] Jain, R.; Mishra, A.P.; "Microwave Assisted Synthesis, Spectroscopic, Thermal and Antimicrobial Studies of Some Transition Metal Complexes of Schiff Base Ligands Containing Thiazole Moiety"; Jordan journal of Chemistry, 7(1); pp9-21; 2012.

[20] Imam, H.; Kumar, B.; and Shafayat, M.D.; "Mixed Ligand Complexes of Transition Metal Chelatesof 1-nitroso-2naphthol and 8-hydroxyquinoline with Picolinic Acid and Quinaldinic acid"; Orien. J. Chem. 27 (1):pp 287-291; 2011.

[21] Dutt, N.K.;Chakder, N.C.; "Complexes of cobalt (II) with some thiocarbazide derivatives." J. Inorg. Nucl. Chem. 33 (2):pp393-403; 1971.

[22] Chow, S.T.; McAuliffe, C.A.; "Metal complexes of amino acids and derivativesXIII Some nickel (II) complexes of L-arginine zwitterions or L-argininate anions. A novel ionic $\rightarrow$ bidentate perchlorate rearrangement brought about by pressure [1-5]"; J. Inorg. Nucl. Chem.; 37(4): pp 1059-1064.1975.

[23] (a) Lever, A. B. P.; Lewis, J.; and Nyholm, R. S.; "Pyrazine metal complexes. Part III. Derivatives of nickel (II)" (0): pp 5042-5048, 1963.

(b) Nicholls, D.; "The Chemistry of Iron, Cobalt and Nickel." $1{ }^{\text {st }}$ Ed., Pergman Press, Oxford; 1973.

[24] Deshmuke, K.G.; Bhobe, R.A.; Spectral, thermal and magnetic properties of $\mathrm{Ni}$ (II) complexes of $p$-phenylazosalicylaldehydes"; J. Inorga. Nucl. Chem.; 40(1):pp135-136; 1978.

[25] Jasim, U.Z.; "Synthesis and Characterization of New Mn(II), Co(II), $\mathrm{Ni}(\mathrm{II})$ and $\mathrm{Cu}(\mathrm{II})$ Complexes with $[\alpha-$ methyl-N-(3-methylidene indol)-2-amino anthraquinone] Ligand"; Colle. Basic. Educ. Res. J.; 10(4):pp570-581; 2011.

[26] Cotton, F. A.; Murillo, A.; Carlos, Bachmann; Manfred; Grimes; Russell, N.; "Advanced Inorganic Chemistry"; 6th Ed., John Wiley \& Sons Inc.;1999. 
[27] Zaky, R .R., Abdelghay, A. M.; "Synthesis, characterization and anticancerous properties of mixed ligand Pd (II) and $\mathrm{Ag}$ (I) complexes with 2 - amino-7oxo-4,5,6,7-tetrahydrobenzo [b]thiophene3-carbonitrile and 2,2'- bipyridyl"; Res. J. Pharma. Biolo . Chem . Scie. ; 2 (1):pp757$764 ; 2011$.

[28] Zoricaleka, Slobodan, A. G.,; Zivoslav, T.; Svetlanalukic, T.; Sonja, S .and Srecko, T.; "The synthesis and characterization of complexes of zinc (II), cadmium (II), platinum (II) and palladium (II) withpotassium 3-dithiocarboxy-3-aza-5amino-pentanoate"; J. Ser. Chem. Soc; 69(2):pp173- 143. ; 2004.

[29] Mason III, W. R.; Gray, H. B.; "Electronic Structures of Square Planar Complexes" Inorg. Chem.; 7 (1): pp 55$58 ; 1968$.

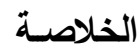

تم تحضير معقدات جديدة من مفاعلة كوانلين -2-

حامض الكربوكسيلي و 4,4'-داي مثيل,2,2'-باي بريديال

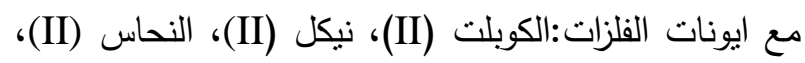

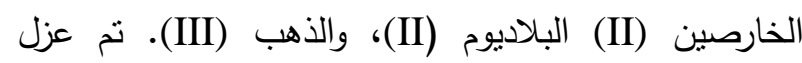
وتتخيص المعقدات الجديدة المحضرة بالطرق الطيفية والفيزيائية كطيف الاشعة تحت الحمراء والاثعة فوق بطنة البنفجية-المرئية والتحليل الدقيق للعناصر وتعيين نسبة التية الفلز والتحليل الحراري فضلا عن القياسيات الحساسية المغناطيسية والتوصيلية. وجد ان المعقدات المحضرة مونمرية

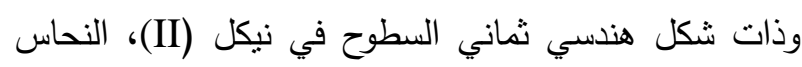

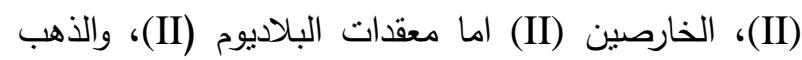
وجدت على شكل مربع مستو، في حين ان الكوبلت (II) المحضرة في الطور الغازي باستخدام برنامجي (Hyper chem.8 and Gaussian program (GaussView Currently Available Versions (5.0.9) along with Gaussian 09 which is the latest in the Gaussian series of programs). 